\title{
Percutaneous Embolisation of Pulmonary Arteriovenous Fistulae in Patients with Hereditary Haemorrhagic Telangiectasia
}

\author{
Eduardo Erudilho1, Júlio Flavio Meirelles Marchini², Mohamad Said Ghandour ${ }^{3}$, \\ Nádia Mendonça Carnieto ${ }^{4}$, Salvador André Bavaresco Cristovão ${ }^{5}$, José Armando Mangione ${ }^{6}$
}

\begin{abstract}
Most cases of pulmonary arteriovenous malformations occur in patients with hereditary hemorrhagic telangiectasia. It is a rare disease that may present with strokelike symptoms in young patients. With the development of occlusion devices, percutaneous embolization has become the treatment of choice. We report a case of a 33 year-old man with a history of multiple strokes, cyanosis, dyspnea, recurrent epistaxis and high flow pulmonary fistulae who was submitted to percutaneous embolization. The patient improved clinically and has had no recurring symptoms in the 30-month follow-up.
\end{abstract}

DESCRIPTORS: Embolization, therapeutic. Arteriovenous fistula. Telangiectasis. Arteriovenous malformations. Pulmonary artery.

$\mathrm{H}$ ereditary hemorrhagic telangiectasia, also known as Rendu-Osler-Weber syndrome, is an autosomal dominant disorder described in the $19^{\text {th }}$ century. It is classically diagnosed by the association of the four Curaçao criteria: recurrent epistaxis, multiple telangiectasias in characteristic sites (lips, oral cavity, fingers, and nose), visceral arteriovenous malformations, and family history. ${ }^{1}$ There are two main types related to mutations of genes involved in the signalling of the transforming
RESUMO

\section{Embolização Percutânea de Fístulas Arteriovenosas Pulmonares em Paciente com Telangiectasia Hemorrágica Hereditária}

A maioria dos casos de malformações arteriovenosas pulmonares ocorre em pacientes portadores de telangiectasia hemorrágica hereditária. É uma doença incomum, que pode se apresentar com acidentes vasculares encefálicos em pacientes jovens. Com o surgimento de dispositivos de oclusão, a embolização percutânea tornouse o tratamento de escolha. Relatamos o caso de um paciente de 33 anos de idade, com história de múltiplos acidentes vasculares encefá licos, cianose, dispneia, epistaxes recorrentes e presença de fístulas pulmonares de alto fluxo, submetido a embolização por via percutânea. O paciente apresentou melhora clínica, encontrandose em acompanhamento há 30 meses, sem sin tomas recorrentes.

DESCRITORES: Embolização terapêutica. Fístula arteriovenosa. Telangiectasia. Malformações arteriovenosas. Artéria pulmonar.

growth factor-beta (TGF- $\beta$ ) superfamily. ${ }^{2}$ Patients with hereditary haemorrhagic telangiectasia type 1 (endoglin) have epistaxis in $50 \%$ of cases at approximately the age of 10 years, and higher frequency of symptomatic pulmonary arteriovenous malformations and brain abscesses, ${ }^{3}$ while patients with hereditary haemorrhagic telangiectasia type 2 (ACVRL1) have epistaxis ten years later than type 1 , and only this type has symptomatic hepatic involvement.

\footnotetext{
1 Interventionist cardiologist physician. Assistant of the team Ariê Cardiologia Intervencionista do Hospital Beneficência Portuguesa de São Paulo. São Paulo, SP, Brazil.

${ }^{2}$ Cardiologist physician. Trainee at the team Ariê Cardiologia Intervencionista do Hospital Beneficência Portuguesa de São Paulo. São Paulo, SP, Brazil.

3 Interventionist cardiologist physician. Assistant of the team Ariê Cardiologia Intervencionista do Hospital Beneficência Portuguesa de São Paulo. São Paulo, SP, Brazil.

${ }^{4}$ Interventionist cardiologist physician. Assistant of the team Ariê Cardiologia Intervencionista do Hospital Beneficência Portuguesa de São Paulo. São Paulo, SP, Brazil.
}

\footnotetext{
${ }^{5}$ Interventionist cardiologist physician. Holder of the team Ariê Cardiologia Intervencionista do Hospital Beneficência Portuguesa de São Paulo. São Paulo, SP, Brazil.

${ }^{6}$ Doctor. Interventionist cardiologist physician. Director of the team Ariê Cardiologia Intervencionista do Hospital Beneficência Portuguesa de São Paulo. São Paulo, SP, Brazil.
}

Correspondence to: Eduardo Erudilho. Rua Maestro Cardim, 768 - $1^{\circ}$ subsolo - sala 73 - Paraíso - São Paulo, SP, Brazil - CEP 01323900 E-mail: eduardoerudilho@gmail.com

Received on: 12/18/2012 • Accepted on: 2/21/2013 
There is marked variation in disease penetration and presentation; it is believed that external factors, such as tissue damage and wounds, are required for neoangiogenesis activation and telangiectasia appearance. The presence of pulmonary arteriovenous malformations allows for the passage of non-oxygenated blood into the left atrium, leading to cyanosis, and the occurrence of cerebrovascular accident is often the initial manifestation.

The present study reports the case of a patient with cyanosis, progressive dyspnoea, recurrent episodes of epistaxis, and four previous cerebrovascular accident episodes.

\section{CASE REPORT}

Male patient, 33 years old, was admitted to the emergency room with reduced level of consciousness, diversion of lip commissure to the right, right dysarthria, and paresthesia, with onset 24 hours earlier. At the consultation, he reported dyspnoea on exertion accompanied by cyanosis, epistaxis episodes since age 15 , two episodes of upper gastrointestinal bleeding, and four ischemic cerebrovascular accidents. Since the patient had epilepsy, neurological monitoring was performed in order to investigate the hypotesis of central nervous system vasculitis. He reported a history of type 1 diabetes mellitus, hypothyroidism, and positive serology for human immunodeficiency virus (HIV), stage A1, with no indication of antiretrovirals. He had an uncle who had frequent episodes of epistaxis and intestinal bleeding. He regularly used NPH insulin, valproic acid, and levothyroxine.

Physical examination showed finger clubbing and telangiectasias on the palate. Laboratory tests showed hemoglobin of $17.3 \mathrm{~g} / \mathrm{dL}$. Magnetic resonance imaging of the brain showed multiple ischemic areas of various ages, consistent with acute, sub-acute, and old lesions. There were no cerebral arteriovenous malformations.

The cardioembolic etiology was investigated through echocardiography with microbubbles by transesophageal route, which showed passage of microbubbles in the left circulation, suggesting the presence of a patent foramen ovale or pulmonary arteriovenous malformations. Transcranial Doppler infused with microbubbles showed presence of large amounts of microbubbles at rest, accentuated during the Valsalva maneuver, strongly indicative of the presence of right-to-left shunt of high conductance.

Based on the clinical manifestations, personal and family history, and laboratory tests, the patient presented the four Curaçao criteria for the definitive diagnosis of hereditary hemorrhagic telangiectasia. ${ }^{4}$

The patient was then submitted to angiography through the right femoral artery and vein, which showed no coronary lesions, preserved left ventricular function, and presence of pulmonary arteriovenous malformations of high flow at the base (large fistulous sac with two adductor arteries, with diameters of $8 \mathrm{~mm}$ and $10 \mathrm{~mm}$ ) and middle third of the right lung (small fistula with an adductor artery of $3.5 \mathrm{~mm}$ in diameter), and patent foramen ovale (Figure 1). There was no hypertension in left and right chambers, arterial saturation was low $(84.2 \%)$, and the calculated flow through the fistula was $0.89 \mathrm{~L} / \mathrm{min}$, with a flow ratio Qp/Qs of 0.83 .

Percutaneous treatment was chosen, which was performed under local anaesthesia and mild sedation (Figures 2 A, B, and C). The patent foramen ovale was occluded using a 25-mm Intrasept ${ }^{\mathrm{TM}}$ prosthesis (Cardia - Burnsville, United States) without complications. After that, adductor artery embolisation of the large pulmonary arteriovenous fistula was performed using 10-mm and 16-mm diameter Amplatzer ${ }^{\mathrm{TM}}$ Vascular Plug prostheses (St. Jude Medical - St. Paul, United States). Despite the proper positioning of the plugs, significant residual flow was observed, and a reassessment after a few days was scheduled.

In a new study performed after five days, only partial thrombosis of the vascular plugs was observed, as well as persistence of high flow through the fistula. A new embolisation was performed using two MWCE35-14-10-Nester coils, one MWCE-35-14-8-Nester coil, three MWCE-35-8-4-Tornado coils, and two MWCE35-8-5-Tornado coils (Cook Medical - Bloomington, United States). These fibrous coils were positioned using the support provided by vascular plugs (Figure 2 D). Additionally, a small fistula was embolised in the middle lobe with one MWCE-38-8-5-Nester coil (Figures 2 E
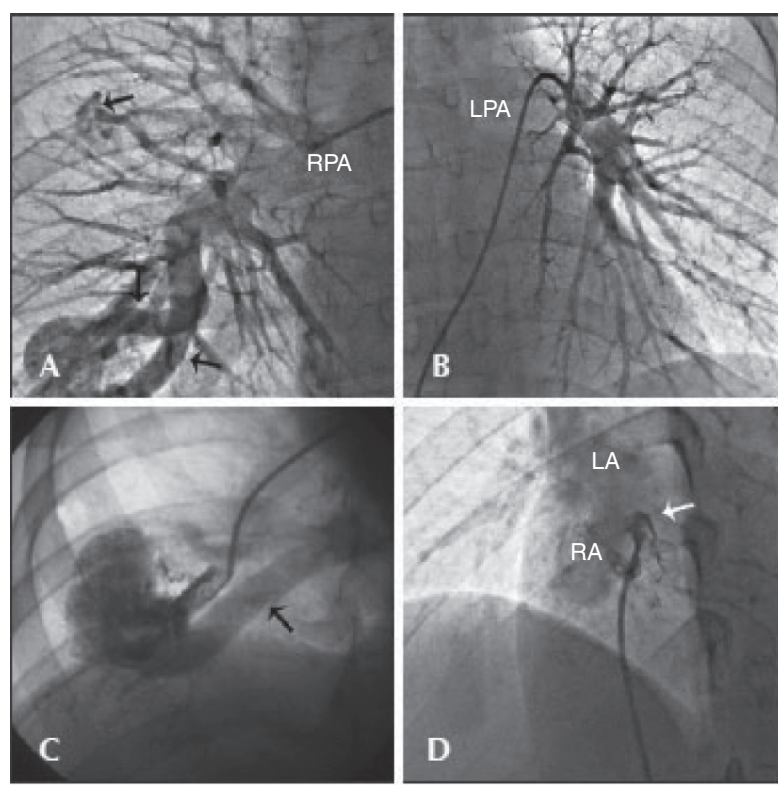

Figure $\mathbf{1}$ - In A, selective injection into the right pulmonary artery showing the presence of arteriovenous malformations, one of which was simple (arrow, upper portion) and another complex, with two adductor arteries (arrows, lower portion). In B, selective injection into the left pulmonary artery showing absence of fistulae. In $\mathbf{C}$, selective injection into the adductor artery showing fistulous sac and involved vein (arrow). In D, injection into the patent foramen ovale in left cranial anterior oblique view showing passage of contrast from the right atrium to the left atrium (arrow). RPA, right pulmonary artery; LPA, left pulmonary artery; LA, left atrium; RA, right atrium. 
and $F$ ). The procedure resulted in complete interruption of flow through the shunts, with immediate improvement of arterial saturation in room air.

The patient was discharged in good clinical condition, on clopidogrel $75 \mathrm{mg} /$ day for six months, and acetylsalicylic acid $200 \mathrm{mg} /$ day for continuous use.

After 12 months, the patient returned to the hospital complaining of headache, nausea, and dizziness. He was hospitalized with suspected meningitis, but the diagnosis was ruled out. A new transcranial Doppler showed the passage of microbubbles, suggesting the appearance of new arteriovenous malformation. Catheterization was performed and the results showed that previously occluded shunts had remained occluded; however, there was a new pulmonary arteriovenous malformation (small fistulous sac with 4-mm adductor artery) in the right lung (Figures $3 \mathrm{~A}$ and 3B), which was successfully embolized using a MWCE-38-5-5-Stainless Steel coil (Figure 3C).
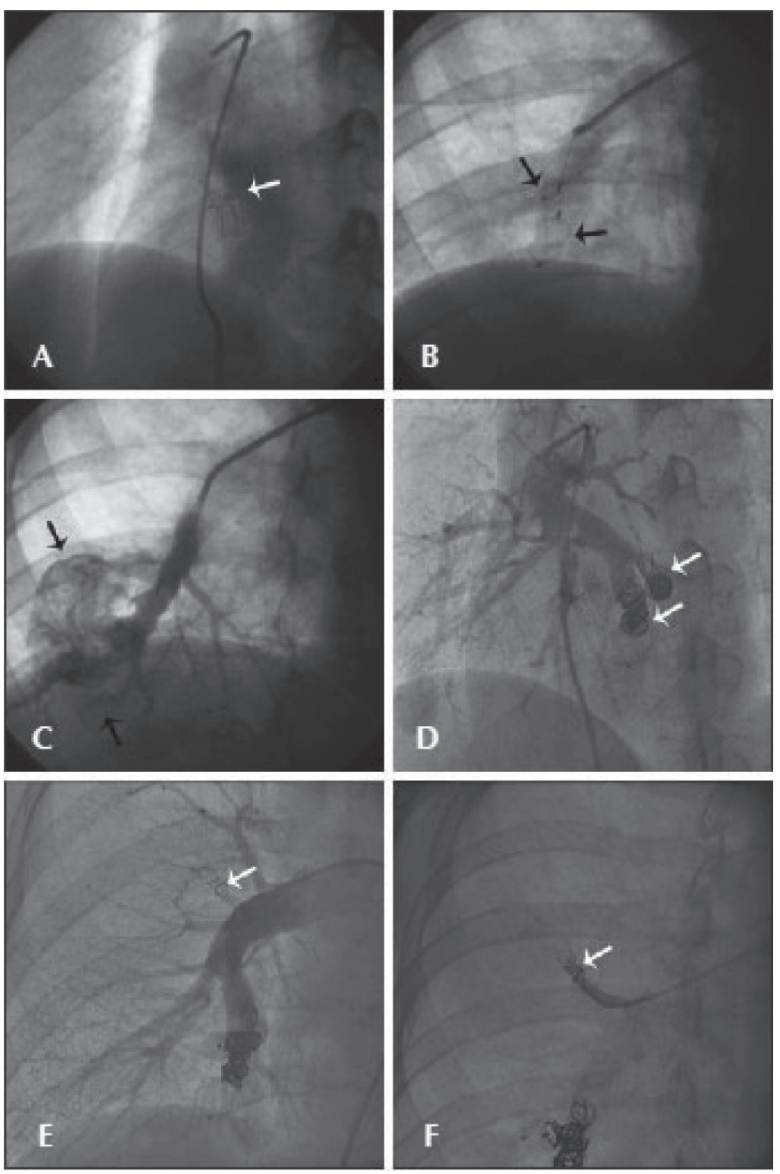

Figure 2 - In A, the immediate result after patent foramen ovale occlusion with Cardia prosthesis (arrow). In B, vascular plugs released in two adductor arteries of the large fistula in the right lung (arrows). In C, the immediate outcome showing residual flow after implantation of vascular plugs (arrows). In D, new procedure performed five days after implantation of additional Gianturco coils, using the plug as an anchor in the adductor arteries of the largest fistulous sac (arrows). In E and F, microfistula occlusion in middle lobe of the right lung with a Gianturco coil (arrow).
The patient has now been followed-up for 30 months after the initial surgery, and did not have further episodes of cerebral embolism, showing improved physical capacity, although with complaints of sporadic episodes of epistaxis.

\section{DISCUSSION}

The rate of development of pulmonary arteriovenous malformations in patients with hereditary hemorrhagic telangiectasia ranges between $20 \%$ to $40 \%$ per year. These fistulas are classified as simple, characterized by a small fistulous sac with one artery and one vein representing $80 \%$ of cases, and complex, with the presence of a more developed fistulous sac with multiple septa and more than one artery and vein. ${ }^{5}$ The present study reported on a case with the presence of simple fistulas in the right upper and lower lobes, as well as a large complex fistula in the right lower lobe, with two adductor arteries and a large vein, resulting in high right-to-left flow.

These patients are at increased risk of paradoxical embolism due to venous thromboembolism or thrombus originating from the arteriovenous malformation itself, which may lead to severe cerebrovascular accident or brain abscess. Percutaneous closure is indicated in all symptomatic patients (cyanosis, hemoptysis, and recurrent cerebrovascular accidents) and in all who have fistulas with arteries $>3 \mathrm{~mm}$ in diameter, who have a higher risk of paradoxical embolism. ${ }^{6}$

There are no randomized studies demonstrating the best treatment option between occlusion or clinical

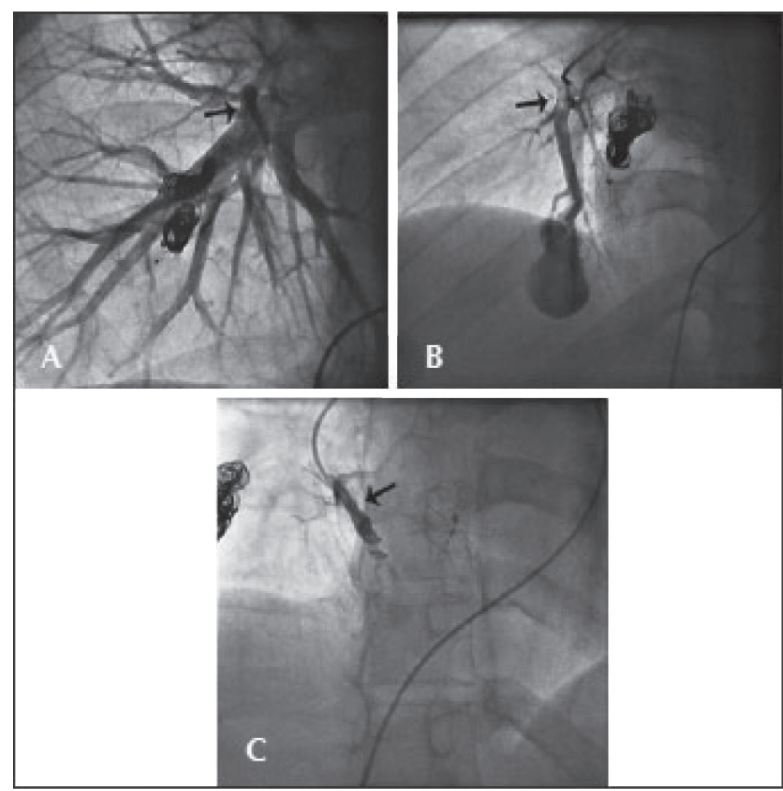

Figure 3 - Angiographic re-evaluation of the patient at 12 months, identifying adductor artery fistula in the right lung in anteroposterior view in A (arrow), and in right anterior oblique view in B (arrow). In C the result immediately after occlusion with the Gianturco coil (arrow). 
treatment. However, there is ample evidence favouring occlusion regarding the decrease in the likelihood of cerebral embolization. Until 1977, the only available treatment was surgical, with morbidity and mortality of up to $4 \%$ to $5 \%$; since then, percutaneous treatment has emerged as the preferred option, since it is safer and more effective.

The main complications of this procedure include device embolization, pleuritic pain, low fever and pleural effusion $(10 \%$ to $35 \%)$, infection, and pulmonary infarction. The contraindications are pulmonary hypertension (moderate and severe) or pulmonary infection. To prevent device displacement, devices should be chosen with a diameter $2-\mathrm{mm}$ greater than the diameter of the vessel to be occluded when using coils, or with a diameter $20 \%$ to $30 \%$ larger than the vessel when employing plugs. ${ }^{7}$

In this case, there was no difficulty in effectively treating simple fistulas with only one coil, but the complex fistula had large-calibre adductor arteries, poorly defined septa in the fistulous sac, and a largecalibre vein, which are predictors of high risk of coil embolization, with dire consequences for the systemic circulation. For this reason, it was chosen to use the Amplatzer ${ }^{\mathrm{TM}}$ Vascular plug with larger dimensions than that of adductor vessels, preventing the risk of embolization. These were important for the posterior positioning of multiple coils due to the persistent flow through the fistula, after five days of follow-up, a technique succesfully used by Pereira et al. ${ }^{8}$

The concomitant presence of patent foramen ovale increased the chance of paradoxical thromboembolism, and, therefore, it was occluded with a 25-mm Cardia prosthesis, guided by transesophageal echocardiography. Although the patent foramen ovale was small, had a short tunnel, and did not present interatrial septal aneurysm, the decision to occlude it was based on the presence of right-to-left shunt through the interatrial septum in a patient with multiple previous episodes of cerebrovascular accident.

The physiopathology of arteriovenous malformation development appears to involve not only the lack of inhibition of the neoangiogenesis pathway due to lack of activation of components of the TGF- $\beta$ receptor superfamily, but also tissue injury. ${ }^{9}$ Within this model, it is expected that new arteriovenous malformations will be established in the future, due to new episodes of injury to which biological tissues are subject. In fact, the recurrence rate is $3 \%$ a year. ${ }^{10}$

Despite the technical difficulty and high risk of occluder device embolization in complex pulmonary arteriovenous malformation, the initial choice of the vascular plug, complemented by fibrous coils, made the percutaneous treatment feasible and safe in this case. It is believed that concomitant treatment of patent foramen ovale was also important for an evolution free of embolic events at the 30-month follow-up.

\section{CONFLICTS OF INTEREST}

The authors declare to have no conflicts of interest.

\section{REFERENCES}

1. Richards-Yutz J, Grant K, Chao EC, Walther SE, Ganguly A. Update on molecular diagnosis of hereditary hemorrhagic telangiectasia. Hum Genet. 2010;128(1):61-77.

2. Dupuis-Girod S, Bailly S, Plauchu H. Hereditary hemorrhagic telangiectasia: from molecular biology to patient care. J Thromb Haemost. 2010;8(7):1447-56.

3. Lesca G, Olivieri C, Burnichon N, Pagella F, Carette MF, Gilbert-Dussardier B, et al. Genotype-phenotype correlations in hereditary hemorrhagic telangiectasia: data from the FrenchItalian HHT network. Genet Med. 2007;9(1):14-22.

4. Shovlin CL, Guttmacher AE, Buscarini E, Faughnan ME, Hyland RH, Westermann CJ, et al. Diagnostic criteria for hereditary hemorrhagic telangiectasia (Rendu-Osler-Weber syndrome). J Med Genet. 2000;91(1):66-7.

5. Reidy JF. Pulmonary arterio-venous fistulas. In: Sievert $H$, Qureshi S, Wilson N, Hijazi Z, editors. Percutaneous interventions for congenital heart disease. Abingdon: Informa UK; 2007. p. 419-22.

6. Abdel-Aal AK, Saddekni S, Underwood E, Oser RF, Vattoth S. Innumerable bilateral pulmonary arteriovenous malformations: percutaneous transcatheter embolization using Amplatzer vascular plug. Vasc Endovascular Surg. 2012;46(6):475-9.

7. Bertog SC, Steinberg DH, Frankie J, Wunderlich N, Sievert H, Ruygrok PN. Closure of arteriovenous fistulae and malformations. In: Eeckhout E, Serruys PW, Williams W, Vahanian A, Van Sambeek M, De Palma R, editors. Percutaneous interventional cardiovascular medicine. Spain: PCR; 2012. p. 446-8.

8. Pereira FL, Ribeiro MS, Costa RN, Braga SLN, Fontes VF, Pedra CAC. Experiência clínica com a utilização de plugs vasculares Amplatzer $^{\circledR}$. Rev Bras Cardiol Invasiva. 2010;18(3):327-36.

9. Park SO, Wankhede M, Lee YJ, Choi EJ, Fliess N, Choe SW, et al. Real-time imaging of de novo arteriovenous malformation in a mouse model of hereditary hemorrhagic telangiectasia. J Clin Invest. 2009;119(11):3487-96.

10. White RI Jr. Pulmonary arteriovenous malformations: how do I embolize?. Tech Vasc Interv Radiol. 2007;10(4):283-90. 